\title{
Two new species of coccidian parasites (Apicomplexa, Eimeriorina) from red drum Sciaenops ocellatus
}

\author{
Jan H. Landsberg \\ Florida Marine Research Institute, State of Florida Department of Natural Resources, 100 Eighth Avenue Southeast, \\ St. Petersburg, Florida 33701-5095, USA
}

\begin{abstract}
Two new species of coccidia, Epieimeria ocellata n. sp. and Goussia floridana n. sp., were found in the intestine of red drum Sciaenops ocellatus (L.) (Sciaenidae) in Florida, USA. Merogony and gamogony stages of both species were 'epicellular' in the microvillous region at epithelial cell apices. In $E$. ocellata, sporogony was intracellular, with endogenous sporulation. Fresh, mature oocysts were roughly spherical $(9.6 \mu \mathrm{m}$ long $\times 9.3 \mu \mathrm{m}$ wide) and had no oocyst residuum. Sporocysts were ellipsoidal $(6.9 \mu \mathrm{m}$ long $\times 4.1 \mu \mathrm{m}$ wide) and had a distinct. Stieda body. Sporozoites were thick $(5.6 \mu \mathrm{m}$ long $\times$ $1.8 \mu \mathrm{m}$ wide), were aligned side by side, and had flexed ends. In $G$. floridana, sporogony was extracellular, with exogenous sporulation. Fresh, mature oocysts were subspherical $(19.9 \mu \mathrm{m}$ long $\times 15.9 \mu \mathrm{m}$ wide) and had no oocyst residuum. Sporocysts were.ellipsoidal $(12.6 \mu \mathrm{m}$ long $\times 7.5 \mu \mathrm{m}$ wide) and had an indistinct suture line. The sporocyst residuum consisted of 1 to 14 granules. Sporozoites were thick $(11.0 \mu \mathrm{m}$ long $\times 3.9 \mu \mathrm{m}$ wide) and occupied most of the sporocyst.
\end{abstract}

\section{INTRODUCTION}

The Florida Department of Natural Resources' (FDNR) Florida Marine Research Institute (FMRI) is conducting a long-term research program to determine the feasibility of increasing depleted feral stocks of red drum Sciaenops ocellatus (L.) (Sciaenidae) by releasing, into the wild, fish cultured at the Stock Enhancement Research Facility (SERF) at Palmetto, Florida, USA. In this program, feral fish are routinely screened for parasites so that baseline information can be developed on characteristic parasites that could become pathogenic in mariculture systems. Several new species of parasites have been discovered during this screening process; this paper describes 2 new coccidian species, Epieimeria ocellata n, sp. and Goussia floridana n. sp., from the intestine of feral red drum.

\section{MATERIALS AND METHODS}

Cultured fish were obtained from SERF during October and November 1990, November 1991, and
January and May 1992. Tagged, cultured-released fish and feral fish were obtained from Bishops Harbor (BH), Manatee County, Florida, in March, April, and July 1992 and from Murray Creek, Volusia County (VC), Florida, during the period from November 1991 to July 1992. Necropsies were performed on 88 fish as part of the parasite classification survey. Tissue portions of 5 to $10 \mathrm{~mm}$ were taken from gill, pseudobranch, posterior kidney, swim bladder, gall bladder, liver, urinary bladder, stomach, ceca, anterior and posterior intestine, spleen, and musculature. Fresh squash preparations of these tissues, as well as of skin and fin scrapings, and blood smears were examined by light microscopy for coccidian stages. Parallel evaluations of these tissues were also made from stained smears or histological preparations. Stained smears were airdried, methanol-fixed, and stained with Giemsa:0.1 M phosphate buffer $(1: 1, \mathrm{pH} 7.4)$ for $20 \mathrm{~min}$. Slides that would be evaluated later were rinsed with $0.1 \mathrm{M}$ phosphate buffer and air-dried.

Histological slides were made from tissues that were fixed in $5 \%$ paraformaldehyde in $0.1 \mathrm{M}$ phosphate buffer, dehydrated in a graded ethanol series, and 
embedded in JB-4 glycol methacrylate resin. Sections were cut to $3.5 \mu \mathrm{m}$ on an LKB 2218 Historange microtome and were stained in Weigert's hematoxylin and eosin (H\&E), in periodic acid/Schiff's hematoxylin metanil yellow (Quintero-Hunter et al. 1991), or in thionin stain adapted to glycol methacrylate (P. Nagle \& I. Quintero-Hunter, FMRI, unpubl.). Representative samples were deposited in the U.S. National Museum (USNM) and in the FDNR Marine Invertebrate Collection at FMRI (FSBC I).

Ten 301 aquaria each held 1 fish from VC. Fecal material was siphoned from the tank bottoms and was examined daily for oocysts. Fresh specimens of sporogony stages taken from fecal casts of at least 5 fish were viewed with differential interference contrast optics and used to make photomicrographs and drawings. All parasite stage dimensions reported for each species are recorded as the mean and range of measurements taken at a magnification of $\times 1000$. To study exogenous sporulation in Goussia floridana, fecal casts were kept in artificial seawater (20 ppt Instant Ocean(8, Aquarium Systems, Inc.) at 20 to $25^{\circ} \mathrm{C}$ and were examined daily for several days. Final sporulating stages were present after $48 \mathrm{~h}$. Measurements of merogony, gamogony, and sporogony stages of both coccidian species (taken from histological sections of fixed tissue) are also given.

\section{RESULTS}

The number of red drum examined and the coccidian prevalence levels are given in Table 1 . There was no apparent extreme pathological effect associated with the presence of either species. Measurements for stages in fresh material and in histological sections are given in Table 2. Descriptions of stages are based on H\&Estained tissues.

\section{Epieimeria ocellata n. sp.}

In histological sections of the intestine, light to moderate levels of infection were present. Merogony and gamogony stages were located in the microvillous region at epithelial cell apices, usually in the anterior or posterior intestine, whereas sporogony stages were intracellular and were primarily found in the posterior intestine. All stages were endogenous.

Mature meronts were roughly spherical and contained 4 to 8 elongate merozoites that had a small, deeply basophilic nucleus and lightly basophilic cytoplasm (Fig. 1). The number of merogonial generations could not be determined. Final merogony stages were ovoid to spherical and yielded at least 4 gamonts that each had a distinct nucleolus in the nucleus (Fig. 2). Early multinucleate microgamonts were subspherical. Immature microgamonts were ovoid with 18 to 28 developing basophilic U-shaped microgametes (Fig. 3). In mature microgamonts up to 34 flagellated microgametes were seen (Fig, 4). Macrogamonts were subspherical to spherical and had a large nucleus and distinct nucleolus (Figs. 3, 5 \& 6). The cytoplasm in mature macrogamonts contained eosinophilic granules (Fig. 6). The ratio of macrogamonts to microgamonts was approximately 6 to 1. Intracellular sporonts were spherical and had a large eosinophilic nucleus and foamy, greyish cytoplasm in stained material and a granular cytoplasm in fresh material (Fig. 7). Intracellular sporulated oocysts containing 4 sporocysts were spherical and were larger than fresh oocysts (Fig. 8). Fresh, mature oocysts were roughly spherical and had no oocyst residuum. Sporocysts were ellipsoidal and had a distinct Stieda body. Thick sporozoites were aligned side by side and had flexed ends (Figs. 9 \& 10).

Table 1. Epieimeria ocellata, Goussia floridana parasitizing Sciaenops ocellatus. Prevalence and geographic distribution of red drum coccidia. SERF: Stock Enhancement Research Facility at Palmetto, Florida; BH: Bishops Harbor; VC: Murray Creek, Volusia County

\begin{tabular}{|c|c|c|c|c|c|}
\hline \multirow[t]{2}{*}{ Site } & \multirow{2}{*}{$\begin{array}{l}\text { No. of } \\
\text { red drum } \\
\text { examined }\end{array}$} & \multirow{2}{*}{$\begin{array}{c}\text { Standard } \\
\text { length } \\
\text { range }(\mathrm{cm})\end{array}$} & \multicolumn{3}{|c|}{ Prevalence (\%) } \\
\hline & & & E. ocellata & G. floridana & Both spp. \\
\hline SERF & 21 & $3.1-8.0$ & 0.0 & 0.0 & 0.0 \\
\hline \multicolumn{6}{|l|}{$\mathrm{BH}$} \\
\hline Feral & 5 & $8.2-21.0$ & 60.0 & 40.0 & 0.0 \\
\hline Tagged & 1 & 11.5 & 100.0 & 100.0 & 100.0 \\
\hline \multicolumn{6}{|l|}{ VC } \\
\hline Feral & 30 & $4.5-18.0$ & 63.3 & 43.3 & 33.3 \\
\hline Tagged & 31 & $5.3-14.3$ & 68.8 & 54.8 & 45.2 \\
\hline
\end{tabular}


Table 2. Epieimeria ocellata, Goussia floridana parasitizing Sciaenops ocellata. Dimensions of parasite stages of red drum coccidia

\begin{tabular}{|c|c|c|c|c|c|}
\hline \multirow[t]{2}{*}{ Stage } & \multicolumn{2}{|c|}{ Length $(\mu \mathrm{m})$} & \multicolumn{2}{|c|}{ Width $(\mu \mathrm{m})$} & \multirow[t]{2}{*}{$\mathrm{n}$} \\
\hline & Mean & Range & Mean & Range & \\
\hline \multicolumn{6}{|l|}{ E. ocellata } \\
\hline \multicolumn{6}{|l|}{ Fixed } \\
\hline Meront & 5.2 & $3.0-7.0$ & 6.2 & $4.0-8.0$ & 21 \\
\hline Merozoite & 4.2 & $3.0-5.0$ & 1.8 & $1.0-2.0$ & 11 \\
\hline Final merogony & 5.2 & $4.0-6.0$ & 6.2 & $4.0-8.0$ & 5 \\
\hline \multicolumn{6}{|l|}{ Microgamont } \\
\hline early & 4.9 & $3.0-8.0$ & 6.2 & $4.0-8.0$ & 14 \\
\hline immature & 5.8 & $4.0-7.0$ & 7.8 & $6.0-10.0$ & 6 \\
\hline mature & 6.4 & $5.0-7.0$ & 8.4 & $7.0-11.0$ & 5 \\
\hline Macrogamont & 6.3 & $5.0-9.0$ & 8.3 & $6.0-13.0$ & 30 \\
\hline Zygote & 10.1 & $7.0-12.0$ & 10.5 & $9.0-12.0$ & 20 \\
\hline Sporulated oocyst & 11.9 & $10.0-14.0$ & 10.9 & $9.0-13.0$ & 30 \\
\hline \multicolumn{6}{|l|}{ Fresh } \\
\hline Sporont & 10.2 & $9.0-12.0$ & 9.5 & $8.0-11.0$ & 30 \\
\hline Sporulated oocyst & 9.6 & $8.0-11.0$ & 9.3 & $8.0-11.0$ & 30 \\
\hline Sporocyst & 6.9 & $6.0-8.0$ & 4.1 & $4.0-5.0$ & 30 \\
\hline Sporozoite & 5.6 & $5.0-7.0$ & 1.8 & $1.0-2.0$ & 10 \\
\hline \multicolumn{6}{|l|}{ G. floridana } \\
\hline \multicolumn{6}{|l|}{ Fixed } \\
\hline Early meront & 5.1 & $2.0-10.0$ & 6.5 & $4.0-8.0$ & 30 \\
\hline Meront & 8.8 & $6.0-13.0$ & 10.2 & $7.0-15.0$ & 8 \\
\hline Merozoite & 3.3 & $3.0-4.0$ & 2.0 & - & 14 \\
\hline Final merogony & 10.0 & $7.0-13.0$ & 9.0 & $8.0-10.0$ & 4 \\
\hline \multicolumn{6}{|l|}{ Microgamont } \\
\hline early & 9.3 & $6.0-13.0$ & 9.1 & $6.0-12.0$ & 30 \\
\hline immature & 9.7 & $9.0-10.0$ & 13.0 & $11.0-14.0$ & 3 \\
\hline mature & 9.5 & $8.0-13.0$ & 10.6 & $8.0-16.0$ & 8 \\
\hline Macrogamont & 11.4 & $7.0-16.0$ & 11.5 & $8.0-16.0$ & 30 \\
\hline Zygote & 14.7 & $11.0-17.0$ & 12.9 & $9.0-15.0$ & 20 \\
\hline \multicolumn{6}{|l|}{ Fresh } \\
\hline Sporont & 19.1 & $15.0-22.0$ & 16.0 & $14.0-18.0$ & 30 \\
\hline Sporulated oocyst & 19.9 & $19.0-21.0$ & 15.9 & $14.0-18.0$ & 30 \\
\hline Sporocyst & 12.6 & $11.0-14.0$ & 7.5 & $7.0-9.0$ & 30 \\
\hline Sporozoite & 11.0 & $10.0-12.0$ & 3.9 & $3.0-4.0$ & 10 \\
\hline
\end{tabular}

Goussia floridana n. sp.

In the moderate to heavy infections found in histological material, coccidian stages were located in the intestine, either in an 'epicellular' position or in the lumen. Merogony, gamogony, and early sporogony stages were usually located in the microvillous region at epithelial cell apices in the ceca or anterior intestine, whereas intermediate sporogony stages were extracellular and were primarily found, either free or in fecal casts, in the lumen of the posterior intestine. Merogony and gamogony stages were endogenous; sporulation was exogenous and was usually completed $48 \mathrm{~h}$ postexcretion at temperatures of 20 to $25^{\circ} \mathrm{C}$.

Early meronts were ovoid to spherical and had a large nucleus containing a distinct nucleolus. Meronts were ovoid and contained up to 20 merozoites (Fig. 11). The number of merogonial generations could not be determined. Final merogony stages were ovoid to spherical and yielded 2 to 8 gamonts that each had a distinct nucleolus in the nucleus (Fig. 12). Early multinucleate microgamonts were ovoid (Fig. 13). Immature microgamonts were ovoid and contained up to 55 developing basophilic, comma-shaped microgametes (Fig. 13). Mature microgamonts contained up to 60 flagellated microgametes that surrounded a small residual body (Figs. $14 \& 15$ ). Macrogamonts were subspherical to spherical and had a large nucleus and distinct nucleolus. The cytoplasm contained numerous eosinophilic granules (Fig. 13). The ratio of macrogamonts to microgamonts was approximately 5:1. Zygotes (Fig. 15) were subspherical to spherical and had a small nucleolus. Numerous eosinophilic granules surrounded the nucleus; the cytoplasm was foamy and also contained refractile granules.

In fresh preparations, newly released unsporulated oocysts were subspherical to spherical, and the cytoplasm was tightly packed against the cell wall (Fig. 16). 


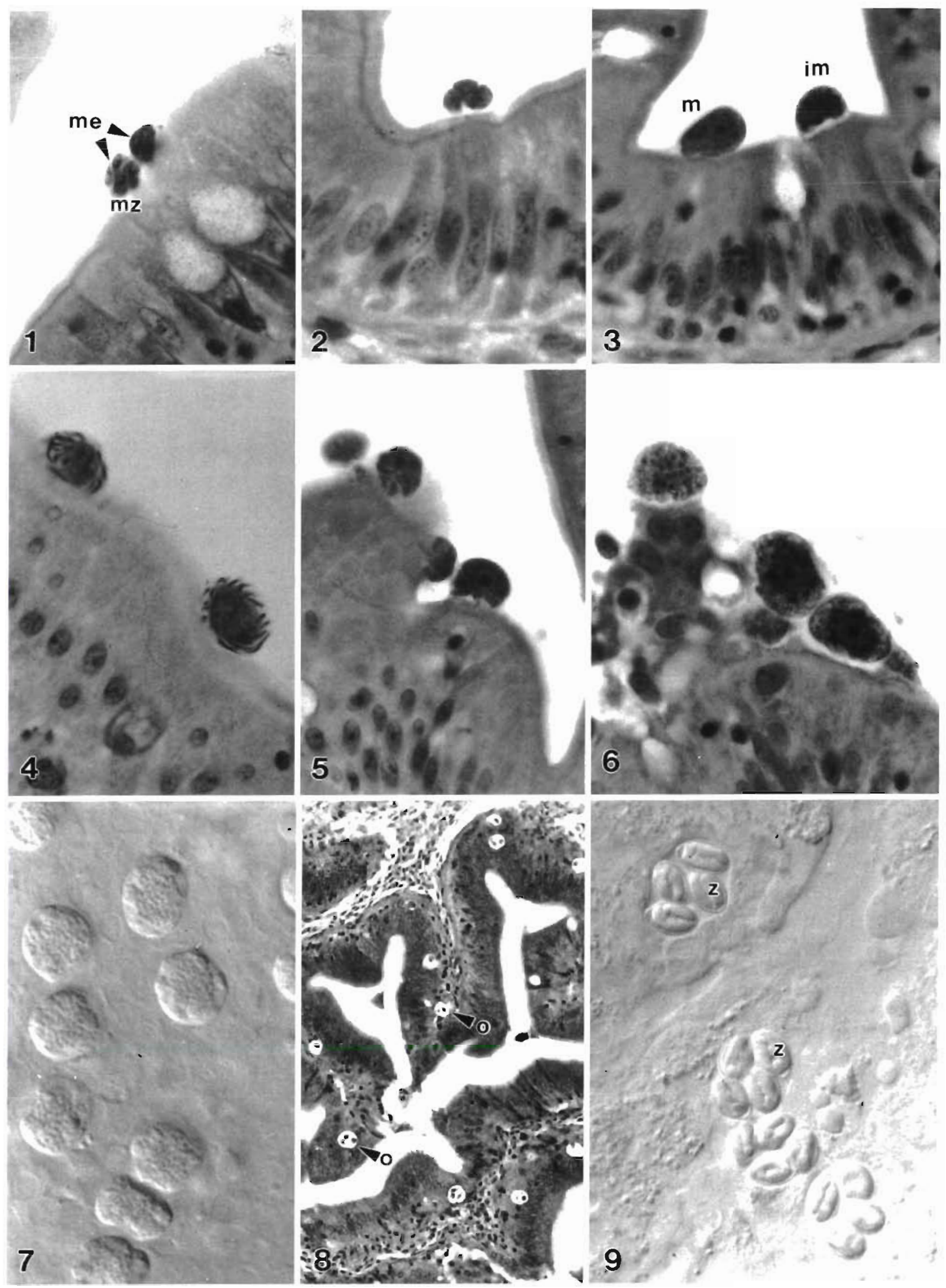


Figs. 1 to 9. Epieimeria ocellata n. sp. Light micrographs of histological sections of anterior intestine stained in thionin (Figs. 1 to 6 ) and posterior intestine stained in H\&E (Fig. 8). Fresh squash preparations of sporogony stages from posterior intestine observed using differential interference contrast microscopy (Figs. 7 \& 9). Fig. 1. Two meronts (me) with merozoites (mz). $\times 1000$. Fig. 2. Final merogony stage showing 3 young gamonts. $\times 1250$. Fig. 3. Immature microgamont (im) with U-shaped microgametes. $\mathrm{m}$ : macrogamont $\times 1000$. Fig. 4 . Two mature microgamonts with flagellated microgametes. $\times 1250$. Fig. 5. Young macrogamonts. $\times 1000$. Fig. 6. Mature macrogamonts with eosinophilic granules. $\times 1500$. Fig. 7 . Sporonts. $\times 1200$. Fig. 8 . Sporulated oocysts (o) $\times 300$. Fig. 9 . Sporozoites $(z)$ in sporulated oocysts. $\times 1300$

After 48 h, fresh sporulated oocysts (Fig. 17) were subspherical and had no oocyst residuum. Sporocysts were ellipsoidal and had an indistinct suture line (Fig. 17). The sporocyst residuum consisted of 1 to 14 granules. Thick sporozoites were aligned side by side and occupied most of the sporocyst (Figs. $17 \& 18$ ).

\section{DISCUSSION}

This is the first report of coccidian species from red drum Sciaenops ocellatus. Only 2 other endoparasitic protozoa have been recorded from this species; Henneguya ocellata from the intestine (Iversen \& Yokel 1963) and Pleistophora sp. from the liver (Overstreet 1983).

Epieimeria ocellata develops 'epicellularly' but light microscopy suggests that merogony, gamogony and early sporogony stages develop beneath the host cell membrane of the intestine in an intracellular, extracytoplasmic position. This can only be confirmed through electron microscopy. Most Epieimeria spp. that have been described are larger than $E$. ocellata n. sp., in which oocysts measure $9.6 \mu \mathrm{m}$ long $\times 9.3 \mu \mathrm{m}$ wide and sporocysts measure $6.9 \mu \mathrm{m}$ long $\times 4.1 \mu \mathrm{m}$. wide. Such other Epieimeria spp. include: $E$. isabellae (Lom \& Dyková 1982) - oocysts are $12.5 \mu \mathrm{m}$ in diameter, and sporocysts are $8.0 \mu \mathrm{m}$ long $\times 5.5 \mu \mathrm{m}$ wide; E. lomae (Daoudi et al. 1987) - oocysts are $11.5 \mu \mathrm{m}$ in diameter, and sporocysts are $6.8 \mu \mathrm{m}$ long $\times 4.7 \mu \mathrm{m}$ wide; E. puytoraci (Daoudi et al. 1989) - oocysts are $13.7 \mu \mathrm{m}$ in diameter, and sporocysts are $8.9 \mu \mathrm{m}$ long $\times 5.0 \mu \mathrm{m}$ wide; $E$. anguillae (Léger \& Hollande 1922) oocysts range from 9.6 to $12.8 \mu \mathrm{m}$ in diameter, and sporocysts are 6.7 to $7.7 \mu \mathrm{m}$ long $\times 3.7$ to $4.2 \mu \mathrm{m}$ wide (Hine 1975). Dimensions of oocysts and sporocysts of E. anguillae are similar to those of E. ocellata n. sp.; however, E. anguillae sporocysts have a distinct hexagonal shape in cross section (Hine 1975), whereas cross sections of E. ocellata sporocysts are circular.

Goussia floridana development is similar to that of a number of other fish coccidians. This type of 'epicellular' development leading to exogenous sporulation has been described for several species that lack a Stieda body in the sporocyst: Eimeria pigra (Léger \& Bory 1932), G. acipenseris (Molnár 1986), G. girellae (Kent et al. 1988), G. janae (Lukeš \& Dyková 1990), G. langdoni
(Molnár \& Rohde 1988), C. pannonica (Molnár 1989), and G. zarnowski (Jastrzebski 1982). In some cases, development has been determined to be intracellular but extracytoplasmic (Lukeš 1992). However, none of these species have oocyst dimensions or characteristics similar to those of $G$. floridana. Substantial variation in cellular location during development has been described in different genera and stages of fish coccidia. Parasite localization strategies can be well defined only when studies regarding mode of transmission and descriptions of all life-cycle stages are complete.

\section{Diagnosis of Epieimeria ocellata n. sp.}

Type host: Red drum Sciaenops ocellatus (Linnaeus, 1758).

Type locality: Atlantic Ocean at Murray Creek, Volusia County, Florida, USA $\left(29^{\circ} 08^{\prime} \mathrm{N}, 80^{\circ} 53^{\prime} \mathrm{W}\right)$. Salinity range was 20 to $31 \mathrm{ppt}$.

Site of infection: Ceca, anterior and posterior intestine. Type slides: Syntype slides of histological sections of anterior and posterior intestine stained in hematoxylin and eosin, together with photomicrographic samples, have been deposited in the USNM, Beltsville, Maryland, USA (number 82652). Two other syntype histological slides stained in thionin have been deposited in the FDNR Marine Invertebrate Collection at FMRI, St. Petersburg, Florida (FSBC I 47995).

Description: Fresh, mature oocysts roughly spherical, $9.6 \mu \mathrm{m}$ long $(8.0$ to $11.0 \mu \mathrm{m}) \times 9.3 \mu \mathrm{m}$ wide $(8.0$ to $11.0 \mu \mathrm{m})$, no oocyst residuum. Sporocysts ellipsoidal, $6.9 \mu \mathrm{m}$ long $(6.0$ to $8.0 \mu \mathrm{m}) \times 4.1 \mu \mathrm{m}$ wide $(4.0$ to $5.0 \mu \mathrm{m})$, a distinct Stieda body. Thick sporozoites, $5.6 \mu \mathrm{m}$ long $(5.0$ to $7.0 \mu \mathrm{m}) \times 1.8 \mu \mathrm{m}$ wide $(1.0$ to $2.0 \mu \mathrm{m})$, aligned side

Fig. 10. Epieimeria ocellata n. sp. Line drawing of a sporulated oocyst. Scale bar $=4.0 \mu \mathrm{m}$

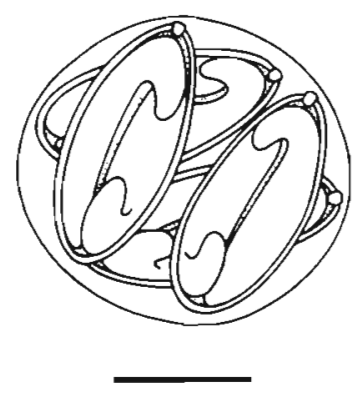




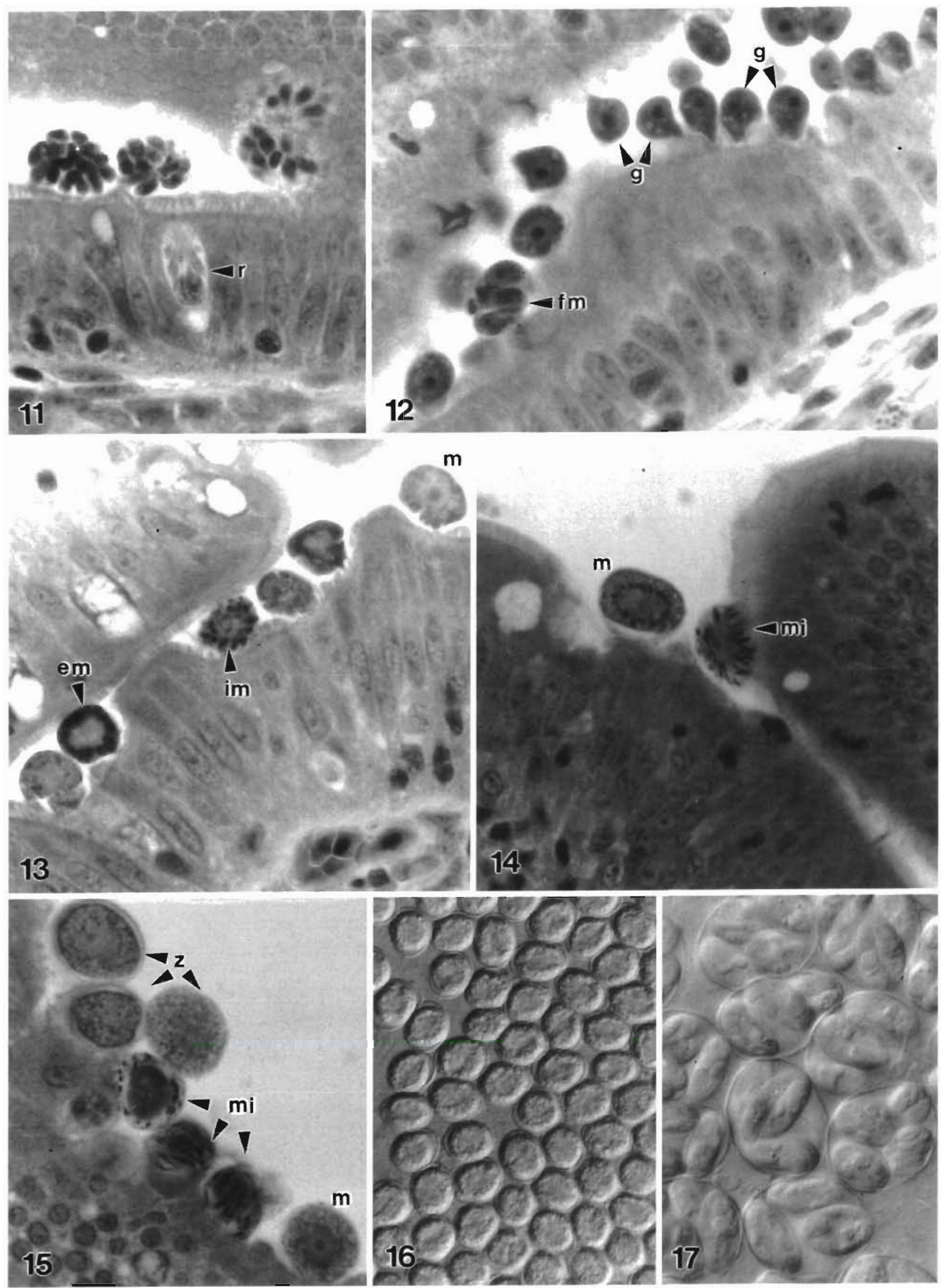


Figs. 11 to 17. Goussia floridana n. sp. Light micrographs of histological sections of anterior intestine stained in H\&E (Figs. 11 to 15). Fresh squash preparation of sporogony stages from fecal smear observed using differential interference contrast microscopy at $0 \mathrm{~h}$ (Fig. 16) and 48 h (Fig. 17). Fig. 11. Meronts with merozoites. r: rodlet cell. $\times 1200$. Fig. 12 . final merogony stage (fm) and young gamonts $(\mathrm{g}) . \times 1250$. Fig. 13. Gamogony stages. em: early multinucleate microgamont; im: immature microgamont; m: macrogamont. $\times 1000$. Fig. 14. Mature microgamont $(\mathrm{mi})$ and macrogamont $(\mathrm{m}) . \times 1000$. Fig. 15 . Mature gamonts and zygotes. m: macrogamont; mi: microgamonts; z: zygote. $\times 1000$. Fig. 16 . Unsporulated oocysts. $\times 400$. Fig. 17 . Sporulated oocysts at $48 \mathrm{~h} . \times 1050$

by side, with flexed ends. Endogenous life cycle Merogony and gamogony stages 'epicellular' in the microvillous region at the apices epithelial cells. Sporogony intracellular.

Etymology: The specific name is taken from the type host species.

\section{Diagnosis of Goussia floridana n. sp.}

Type host: Red drum Sciaenops ocellatus (Linnaeus, 1758). Type locality: Gulf of Mexico at Bishops Harbor, Tampa Bay, Manatee County, Florida, USA (2738' N, $82^{\circ} 35^{\prime} \mathrm{W}$ ). Salinity range was 25 to $30 \mathrm{ppt}$

Site of infection: Ceca, anterior and posterior intestine. Type slides: Syntype slides of histological sections of ceca and anterior intestine stained in hematoxylin and eosin, together with photomicrographic samples, have been deposited in the USNM, Beltsville, Maryland, USA (number 82653). Two other syntype histological slides stained in thionin have been deposited in the FDNR Marine Invertebrate Collection at FMRI, St. Petersburg, Florida (FSBC I 47994).

Description: Fresh, mature oocysts subspherical in diameter, $19.9 \mu \mathrm{m}$ long $(19.0$ to $21.0 \mu \mathrm{m}) \times 15.9 \mu \mathrm{m}(14.0$ to $18.0 \mu \mathrm{m})$, no oocyst residuum. Sporocysts ellipsoidal, $12.6 \mu \mathrm{m}$ long $(11.0$ to $14.0 \mu \mathrm{m}) \times 7.5 \mu \mathrm{m}$ wide $(7.0$ to $9.0 \mu \mathrm{m})$, indistinct suture line. The sporocyst residuum consisted of 1 to 14 granules. Thick sporozoites, $11.0 \mu \mathrm{m} \operatorname{long}(10.0$ to $12.0 \mu \mathrm{m}) \times 3.9 \mu \mathrm{m}$ wide $(3.0$ to $4.0 \mu \mathrm{m})$, aligned side by side and occupying most of the sporocyst. Merogony and gamogony stages 'epicellular' in the microvillous region at the apices of epithelial cells. Sporogony exogenous.

Etymology: The specific name is taken from the type geographic location.

Fig. 18. Goussia floridana n. sp. Line drawing of a sporulated oocyst. Scale bar $=5.0 \mu \mathrm{m}$
Acknowledgements. The research described in this study was supported by funding from the Department of the Interior U.S. Fish and Wildlife Service, Federal Aid for Sportfish Restoration, Project Number F-44. I thank members of the Experimental Culture and Physiology Section at FMRI for their support; Kathy Childress for providing fish; Noretta Perry and Shirley Richards for histological support, Ruth Reese, Judy Leiby, William Lyons, and David Camp for their comments on the manuscript; and Llyn French for drawings.

\section{LITERATURE CITED}

Daoudi, F., Radujković, B., Marquès, A., Bouix, G. (1987). Nouvelles espèces de Coccidies (Apicomplexa, Eimeriidae) des genres Eimeria Schneider, 1875, et Epieimeria Dyková et Lom, 1981, parasites de poissons marins de la baie de Kotor (Yougoslavie). Bull. Mus. natn. Hist. nat., Paris 9: $321-332$

Daoudi, F., Radujković, B., Marquès, A., Bouix, G. (1989). Nouvelles espèces de Coccidies (Apicomplexa, Eimeriidae) des genres Eimeria Schneider, 1875, et Epieimeria Dyková et Lom, 1981, parasites des poissons marins méditerranéens. Bull. Mus. natn. Hist. nat., Paris 11. 743-753

Hine, P. M. (1975). Eimeria anguillae Léger \& Hollande, 1922 parasitic in New Zealand eels. N.Z. J. mar. Freshwat. Res. 9: $239-243$

Iversen, E. S., Yokel, B. (1963). A myxosporidian (sporozoan) parasite in the red drum Sciaenops ocellatus. Bull. mar. Sci. Gulf Caribb. 13: 449-453

Jastrzebski, M. (1982). New species of intestinal coccidia in freshwater fish. Bull. Acad. pol. Sci. 30: 7-11

Kent, M. L., Fournie, J. W., Snodgrass, R. E., Elston, R. A. (1988). Goussia girellae n. sp. (Apicomplexa: Eimeriorina) in the opaleye Girella nignicans. J. Protozool. 35: $287-290$

Léger, M., Bory, T. (1932). Eimeria pigra n. sp., nouvelle Coccidie juxtaépithéliale, parasite du gardon rouge. $\mathrm{C}$. $\mathbf{r}$. hebd. Séanc. Acad. Sci., Paris 194: 1710-1712

Léger, L., Hollande, G. C. (1922). Coccidie de l'intestine de l'anguille. C. r. hebd. Séanc. Acad. Sci., Paris 168: 904-906

Lom, J., Dyková, I. (1982). Some marine fish coccidia of the genera Eimeria Schneider, Epieimeria Dyková \& Lom and Goussia Labbé. J. Fish Dis. 5: 309-321

Lukeš, J. (1992). Life cycle of Goussia pannonica (Molnár, 1989) (Apicomplexa, Eimeriorina), an extracytoplasmic coccidium from the white bream Blicca bjoerkna. J. Protozool. 39: 484-494

Lukeš, J., Dyková, I. (1990). Goussia janae n. sp. (Apicomplexa, Eimeriorina) in dace Leuciscus leuciscus and chub L. cephalus. Dis. aquat. Org. 8: 85-90

Molnár, K. (1986). Occurrence of two new Goussia species in the intestine of the sterlet Acipenser ruthenus. Acta vet. hung. 34: 169-174

Molnár, K. (1989). Nodular and epicellular coccidiosis in the 
intestine of cyprinid fishes. Dis. aquat. Org. 7:1-12

Molnár, K., Rohde, K. (1988). Seven new coccidian species from marine fishes in Australia. Syst. Parasitol. 11: 19-29

Overstreet, R. M. (1983). Aspects of the biology of the red drum, Sciaenops ocellatus, in Mississippi. Gulf Res. Rep. 1: 45-68

Responsible Subject Editor: W. Körting, Hannover, Germany
Quintero-Hunter, I., Grier, H., Muscato, M. (1991). Enhancement of histological detail using metanil yellow as a counterstain in periodic acid/Schiff's hematoxylin staining of glycol methacrylate tissue sections. Biotech. Histochem. 66: $169-172$

Manuscript first received: January 25, 1993 Revised version accepted: May 3, 1993 